\title{
Agroresidues enhanced peroxidase activity expression by Bacillus sp. MABINYA-1 under submerged fermentation
}

\author{
Ayodeji O. Falade ${ }^{1,2,3^{*}} \mathbb{D}$, Leonard V. Mabinya ${ }^{1,2}$, Anthony I. Okoh ${ }^{1,2}$ and Uchechukwu U. Nwodo ${ }^{1,2}$
}

\begin{abstract}
Agroresidues have continued to gain preference over conventional carbon sources for microbial enzyme production due to the low price and abundance in the environment. Therefore, this study aimed at improving peroxidase yield by Bacillus sp. MABINYA-1 (BMAB-1) using agroresidues under submerged fermentation. The culture parameters that support maximum peroxidase yield by BMAB-1 was initially determined and the results showed that peroxidase activity expression was optimum at $\mathrm{pH} 5,30^{\circ} \mathrm{C}$ and $150 \mathrm{rpm}$ while veratryl alcohol and ammonium sulphate served as the best peroxidase-inducer and inorganic nitrogen source, respectively. BMAB-1 exhibited maximum peroxidase expression $(17.50 \pm 0.10 \mathrm{U} / \mathrm{mg}$ ) at $72 \mathrm{~h}$ using kraft lignin liquid medium (KLLM) under the optimized culture conditions. Upon utilization of selected agroresidues (sawdust, wheat straw and maize stover) as sole carbon sources by BMAB-1 in the fermentation process, peroxidase activity was significantly enhanced when compared with glucose $(14.91 \pm 0.31 \mathrm{U} / \mathrm{mg})$ and kraft lignin $(17.50 \pm 0.10 \mathrm{U} / \mathrm{mg})$. Sawdust produced the highest peroxidase yield $(47.14 \pm 0.41 \mathrm{U} / \mathrm{mg})$, followed by maize stover $(37.09 \pm 0.00 \mathrm{U} / \mathrm{mg})$ while wheat straw yielded the lowest peroxidase specific activity $(21.65 \pm 0.35 \mathrm{U} / \mathrm{mg})$. This indicates that utilization of sawdust by BMAB-1 resulted in 3.2- and 2.7fold increase in peroxidase activity expression as compared to glucose and kraft lignin, respectively. The aptitude of BMAB-1 to utilize agroresidues would reduce the cost of peroxidase production by the bacteria since the substrates are cheaper than the conventional carbon sources and are, as well, more readily available.
\end{abstract}

Keywords: Culture conditions, Maize stover, Peroxidase, Sawdust, Submerged fermentation, Wheat straw

\section{Introduction}

Peroxidase has continued to gain attention, probably, due to the robust industrial application potentials; notably, the emerging role in bioremediation that has extensively been documented (Min et al. 2015; Taboada-Puig et al. 2015; Falade et al. 2018). Peroxidases are characterized by promising application potential in the bioenergy sector as members of class-II peroxidase-catalase superfamily (lignin peroxidase, manganese peroxidase and versatile peroxidase) are efficient lignin degraders. Hence, they are part of the suggested "lignocellulolytic enzyme

\footnotetext{
*Correspondence: ayodeji.falade@yahoo.com

1 SAMRC Microbial Water Quality Monitoring Centre, University of Fort

Hare, Private Bag X1314, Alice 5700, Eastern Cape, South Africa

Full list of author information is available at the end of the article
}

system" for biological delignification of feedstock for biofuel production (Wang et al. 2013; Falade et al. 2017a). Peroxidase has also been applied for analytical purposes including development of diagnostic kits for determination of "uric acid and glucose" (Regalado et al. 2004). Other applications of peroxidase include but not limited to development of biosensor, skin-lightening cream and biobleaching of paper pulp (Saleem et al. 2018). Due to the enormous application potentials of peroxidase in different industrial sectors, increased demand is unavoidable. Hence, it is important to increase peroxidase yield and continue to explore novel sources with capacity for improved peroxidase production.

Enzyme yields have been improved over the years using two main approaches. The first one is genetic engineering, which involves "classical mutagenesis and screening" 
and "rational design" (Arnau et al. 2020). Examples of rational design strategies include the use of "stronger promoters and multicopy strains" to improve enzyme production by overexpression of the target gene; "gene deletion"; and "gene fusions" for improved production (Arnau et al. 2020). The second approach, which is more or less preliminary, is the "optimization of culture and nutritional conditions" of microorganisms for improved enzyme yield through the conventional method of "one variable at a time" or response surface methodology (RSM). In the conventional approach, culture conditions that are important for microbial growth $(\mathrm{pH}$, temperature and agitation) and metabolic activities are determined because the continuous production of enzymes has been linked to microbial growth (Niladevi and Prema 2008; Musengi et al. 2014). In addition, nutritional components of the fermentation medium including carbon and nitrogen sources are also significant to the growth of microorganisms. The choice of carbon source is vital because it provides the required energy for the microbial strain. Most bacteria utilize "simple sugars" as carbon sources, but simple sugars and other synthetic sources of carbon are expensive, hence, contributing to the high cost of enzyme production. Besides, simple sugars may not be the most appropriate carbon source for production of inducible enzymes including peroxidases, which may require the introduction of an "inducer" in the growth medium. It is, thus, necessary to explore cheap alternative carbon sources capable of inducing increased enzyme expression.

Waste biomass seems to be a promising alternative to the costly conventional carbon sources including glucose, fructose and xylose as they are readily available and abundant in the environment. Several thousands of tons of lignocellulosic wastes are generated from the agroindustrial sector annually, with no adequate provision for proper disposal. As such, they are burnt, thereby causing environmental pollution (Falade et al. 2017a). Therefore, bioprospecting of lignocellulosic wastes as raw materials for enzyme production becomes an imperative.

Recent studies have reported the utilization of agroresidues (sawdust, wheat straw, wheat bran, corn stover, corn cob, mandarin peels, etc.) for microbial enzyme production (Ijoma et al. 2018; Unuofin et al. 2019; Falade et al. 2019a). Unuofin et al. (2019) valorized maize stover for improved laccase production by two $\gamma$-proteobacteria strains. Also, Falade et al. (2019a) reported the usage of some agricultural residues by a Raoultella species for maximum peroxidase secretion. Recently, Kumar et al. (2020) valorized a wide range of agroresidues including "rice bran, wheat bran, sawdust, banana peel, orange peel, potato peel, pea peel and sugarcane bagasse" for enhanced laccase yield by Bacillus sp. AKRC01. There is, however, paucity of information on the utilization of lignocellulosic waste biomass for peroxidase production by Bacillus species. This present study, therefore, aimed at improving peroxidase yield of BMAB-1 using some agroresidues as carbon sources in a submerged fermentation.

\section{Materials and methods}

\section{Source of microorganism}

BMAB-1 was isolated from soil sample collected from Hogsback forest reserve in Eastern Cape Province, South Africa, as described in a previous study (Falade et al. 2017b). The bacteria was tested for ligninolytic and peroxidase-producing abilities as reported in an earlier study (Falade et al. 2019b). The ligninolytic potential was determined by its aptitude to metabolize "lignin model compounds: guaiacol and veratryl alcohol" (Taylor et al. 2012) while it was positive to a plate screening for peroxidase activity by "yellowish-brown" colouration after reacting with a mixture of " $0.4 \%(\mathrm{v} / \mathrm{v})$ hydrogen peroxide" and "1\% pyrogallol" on nutrient agar (Falade et al. 2017b). Subsequently, the bacteria was identified using 16S rRNA gene sequence analysis (Falade et al. 2019b). Bioinformatics analysis involving the use of Basic Local Alignment Search Tool (BLAST) in the National Center for Biotechnology Information (NCBI) database revealed the identity of the bacteria as a Bacillus species as it had $99 \%$ similarity to Bacillus sp. NC62 (KY454505). Hence, it was identified as Bacillus sp. MABINYA-1, with the GenBank accession number, KX640920.

\section{Submerged fermentation (SMF) for peroxidase production}

The enzyme was produced in a SMF process using the method of Falade et al. (2017b). About 2\% standardized bacterial suspension (OD $600 \mathrm{~nm} \approx 0.1$ ) was inoculated in a kraft lignin liquid medium (KLLM) comprising the following components: $\mathrm{K}_{2} \mathrm{HPO}_{4}, \mathrm{KH}_{2} \mathrm{PO}_{4}, \mathrm{MgSO}_{4}$, $\mathrm{NH}_{4} \mathrm{NO}_{3}$, yeast extract and kraft lignin with 4.55, 0.53, $0.5,5.0,0.1 \mathrm{~g} / \mathrm{L}$ and $0.1 \% \mathrm{w} / \mathrm{v}$ as the respective concentrations. Subsequently, the culture was incubated for $48 \mathrm{~h}$ using the conditions for isolation (temperature: $30^{\circ} \mathrm{C} ; \mathrm{pH}$ : 7.0; and agitation rate: $140 \mathrm{rpm}$ ). The enzyme was prepared by removing the bacterial cells through centrifugation at $10,000 \times g$ in a SIGMA $1-14 \mathrm{~K}$ cold centrifuge. The recovered supernatant, which served as crude enzyme, was subsequently, assayed for peroxidase activity.

\section{Assessment of expressed peroxidase activity}

The level of peroxidase produced by BMAB-1 was assessed by the exoperoxidase activity using the procedure of Chance and Maehly (1955) with slight changes. Details of the modifications have been reported earlier (Falade et al. 2017b). 


\section{Evaluation of culture conditions for optimum peroxidase activity expression}

The various culture parameters favourable for maximum peroxidase expression by BMAB-1 were determined through the conventional one-variable-at-a-time (OVAT) approach (Falade et al. 2019b). BMAB-1 was cultured in KLLM with initial $\mathrm{pH}$ ranging from 3 to 11 . The medium $\mathrm{pH}$ was adjusted using one molar hydrochloric acid and sodium hydroxide as appropriate. Subsequently, the temperature that promotes optimum peroxidase expression by BMAB-1 was determined by cultivating the bacteria at different temperatures $\left(20-45^{\circ} \mathrm{C}\right)$ for $48 \mathrm{~h}$, whereas the optimal agitation rate was determined by incubating the culture in an orbital shaker at different agitation rates (0-200 rpm) under predetermined optimal temperature. The observed optimal culture parameters were subsequently, used for further fermentations.

\section{Influence of lignols on peroxidase activity expression}

The influence of augmenting KLLM with varied lignols on peroxidase activity expression by BMAB-1 was evaluated using the method of Musengi et al. (2014). The bacteria was cultured in KLLM supplemented with $1 \mathrm{mM}$ of selected lignols including guaiacol, veratryl alcohol and vanillin under culture conditions for optimum peroxidase production predetermined in this study.

\section{Influence of inorganic nitrogen supplementation on peroxidase activity expression}

The influence of inorganic nitrogen supplementation on peroxidase activity expression was evaluated by cultivating the bacteria in KLLM augmented with various inorganic nitrogen including $\mathrm{NH}_{4} \mathrm{NO}_{3} ; \mathrm{NH}_{4} \mathrm{Cl}$ and $\left(\mathrm{NH}_{4}\right)_{2} \mathrm{SO}_{4}$ under optimized conditions for peroxidase production $\left(30{ }^{\circ} \mathrm{C}\right.$, pH 5 and $\left.150 \mathrm{rpm}\right)$ with veratryl alcohol as the most effective lignol.

\section{Time course assay}

Exoperoxidase activity expression by BMAB-1 and the growth rate of the bacterial cells were assessed for $144 \mathrm{~h}$ (Tuncer et al. 1999). BMAB-1 was cultivated in KLLM under optimized process conditions predetermined in this study. Subsequently, culture was aseptically withdrawn every $24 \mathrm{~h}$ for peroxidase activity assay and determination of non-peroxide-dependent enzyme activity while the protein content was evaluated (Bradford 1976; Falade et al. 2019a) simultaneously with the bacterial cell growth, which was assessed by reading the absorbance of the culture at $600 \mathrm{~nm}$. We expressed the enzyme specific activity as unit of enzyme per milligram of protein.

\section{Exploitation of agroresidues for improved peroxidase} activity expression

The following agroresidues: sawdust, wheat straw and maize stover, obtained from Alice area in South Africa, were processed as described by Falade et al. (2019a) and then, optimized as carbon sources for peroxidase secretion by BMAB-1 in a SMF. The different agroresidues $(1 \%$ $\mathrm{w} / \mathrm{v}$ ) were used in place of kraft lignin in KLLM. Peroxidase activity expressed by the bacteria when grown on the agroresidues was then compared with the enzyme activity expressed upon glucose and kraft lignin utilization as carbon sources.

\section{Data analysis}

Data generated were analyzed using one-way ANOVA accompanied by Tukey's and Dunnett's post tests as appropriate, with the use of Graph Pad Prism 7.0. Significance was recognized at $95 \%$ confidence interval $(p \leq 0.05)$.

\section{Results and discussion \\ Evaluation of culture conditions for maximum peroxidase activity expression}

The various culture parameters $(\mathrm{pH}$, temperature and agitation) that promote maximum peroxidase expression by BMAB-1 was initially determined because such microbial growth factors have been linked to persistent enzyme secretion.

Firstly, the initial medium $\mathrm{pH}$ that promotes optimum peroxidase secretion by BMAB-1 was assessed and the result is given in Fig. 1. The result showed that peroxidase activity expressed by the test bacteria across the $\mathrm{pH}$ range differs significantly $(p<0.05)$. It is remarkable that BMAB-1 expressed significant exoperoxidase activity over a broad $\mathrm{pH}$ range (3-11) with the highest activity recorded at $\mathrm{pH} 5(6.65 \pm 0.23 \mathrm{U} / \mathrm{ml})$. The aptitude of BMAB-1 to exhibit significant peroxidase activity at very low $\mathrm{pH}$ (3 and 4) indicates that the bacteria is acidophilic in nature. The extremophilic attribute of this bacteria is notable as extremophiles are known for their uniqueness in tolerating harsh environmental conditions, which makes them promising biotechnological candidates. More so, enzymes produced by extremophiles tend to be remarkably stable under extreme conditions (Dumorne 2018). In other words, enzymes from acidophilic bacteria are stable and active at very low $\mathrm{pH}$ and as such hold great biotechnological potential (Jackson et al. 2007; Sharma et al. 2016; Dumorne 2018). Our result concurs with some prior studies, where peroxidase production was optimum at acidic $\mathrm{pH}$ region. 


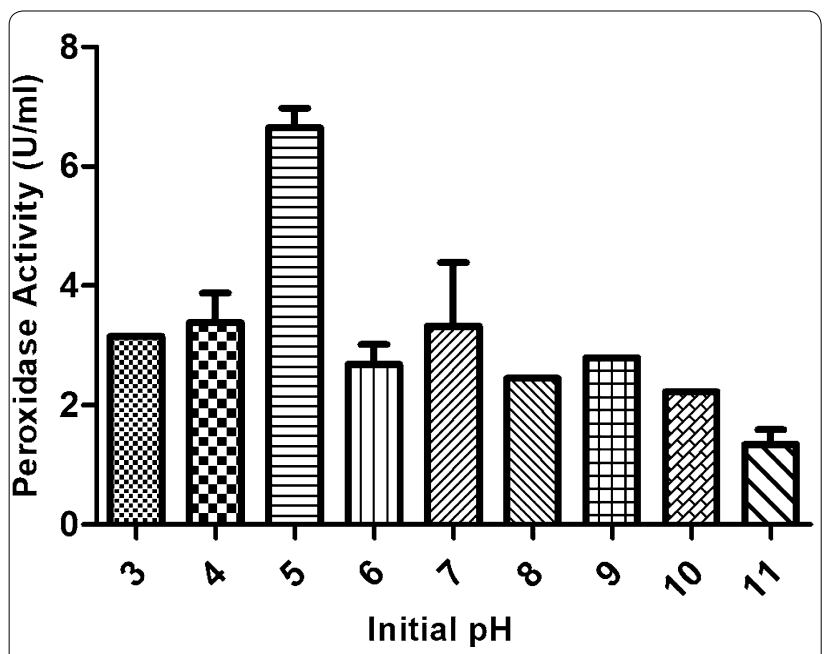

Fig. 1 Initial medium $\mathrm{pH}$ for optimum peroxidase activity expression by BMAB-1

A recent study reported maximum peroxidase yield by a Raoultella species at pH 5 (Falade et al. 2019a). This is corroborated by Rao and Kavya (2014), whose findings revealed $\mathrm{pH} 6$ as the most favourable for optimum peroxidase activity expression by a Bacillus species. These findings may be attributed to the electric charge on the bacterial cell. Since the cell wall of Bacillus species and other Gram-positive bacteria are negatively charged, the bacterial strain tends to thrive more in an acidic environment, made up of more hydrogen ions $\left(\mathrm{H}^{+}\right)$. More so, the "electric charge on the bacterial cell" is imperative for absorption of nutrient with consequent effect on the microbial growth (Falade et al. 2019a).

The influence of temperature on peroxidase secretion by BMAB-1 is presented in Fig. 2. The result showed that peroxidase activity across the examined temperatures $\left(25-45^{\circ} \mathrm{C}\right)$ was significantly different $(p<0.05)$, with the highest activity expressed at $30{ }^{\circ} \mathrm{C}(6.70 \pm 0.23 \mathrm{U} / \mathrm{ml})$. However, the difference in peroxidase activity observed at $40{ }^{\circ} \mathrm{C}(2.33 \pm 0.00 \mathrm{U} / \mathrm{ml})$ and $45{ }^{\circ} \mathrm{C}(1.58 \pm 0.06 \mathrm{U} / \mathrm{ml})$ was not significant $(p>0.05)$. Our finding is comparable to what was reported by Rajkumar et al. (2013), where the optimal temperature for peroxidase secretion by a Bacillus species was $30^{\circ} \mathrm{C}$. More so, $30^{\circ} \mathrm{C}$ has been reported as optimal temperature for peroxidase production by some other bacteria belonging to a different genus. One of such bacteria is Ensifer adhaerens NWODO-2, which similarly, expressed optimum peroxidase activity at $30{ }^{\circ} \mathrm{C}$ (Falade et al. 2019c). Nonetheless, $37{ }^{\circ} \mathrm{C}$ was the most favourable temperature for Bacillus subtilis with regard to peroxidase production (Rao and Kavya 2014). It is clear that peroxidase secretion by most of the reported bacteria was optimal at the mesophilic range. The decreased peroxidase activity observed at $25{ }^{\circ} \mathrm{C}$ and temperatures greater than $30{ }^{\circ} \mathrm{C}$ in this study is perhaps, consequent upon reduced metabolic activities with resultant effect on peroxidase biosynthesis by the test bacteria (Ray et al. 2007; Tandon and Sharma 2014).

Furthermore, we evaluated the effect of agitation on peroxidase activity expression by BMAB-1 and the result is presented in Fig. 3. The result showed that peroxidase activity across the agitation rates was significantly different $(p<0.05)$. However, Dunnett's post test showed that the enzyme activity expressed by BMAB-1 at 50 and $100 \mathrm{rpm}$ does not differ significantly $(p>0.05)$ when compared with static condition $(0 \mathrm{rpm})$. Nevertheless, the bacteria expressed optimal peroxidase activity at $150 \mathrm{rpm}(3.85 \pm 0.82 \mathrm{U} / \mathrm{ml})$, which significantly differs $(p<0.05)$ from the enzyme activity at static condition $(0.58 \pm 0.00 \mathrm{U} / \mathrm{ml})$. It is obvious that high agitation rate was more advantageous towards expression of peroxidase activity by BMAB-1. This finding is justifiable because agitation is capable of affecting the degree of "aeration" and promotes efficient mixing of nutrients in the fermentation medium (McNeil et al. 2006). Therefore, increased agitation is likely to encourage nutrient accessibility to the bacteria thereby, affecting the growth and consequently, the enzyme production. On the other hand, an increase in agitation speed beyond $150 \mathrm{rpm}$ caused a significant reduction in peroxidase activity at $200 \mathrm{rpm}(2.33 \pm 0.81 \mathrm{U} / \mathrm{ml})$, which is attributable to "foaming or shearing stress" exerted on the bacterial cells through agitation (Falade et al. 2019c). This result

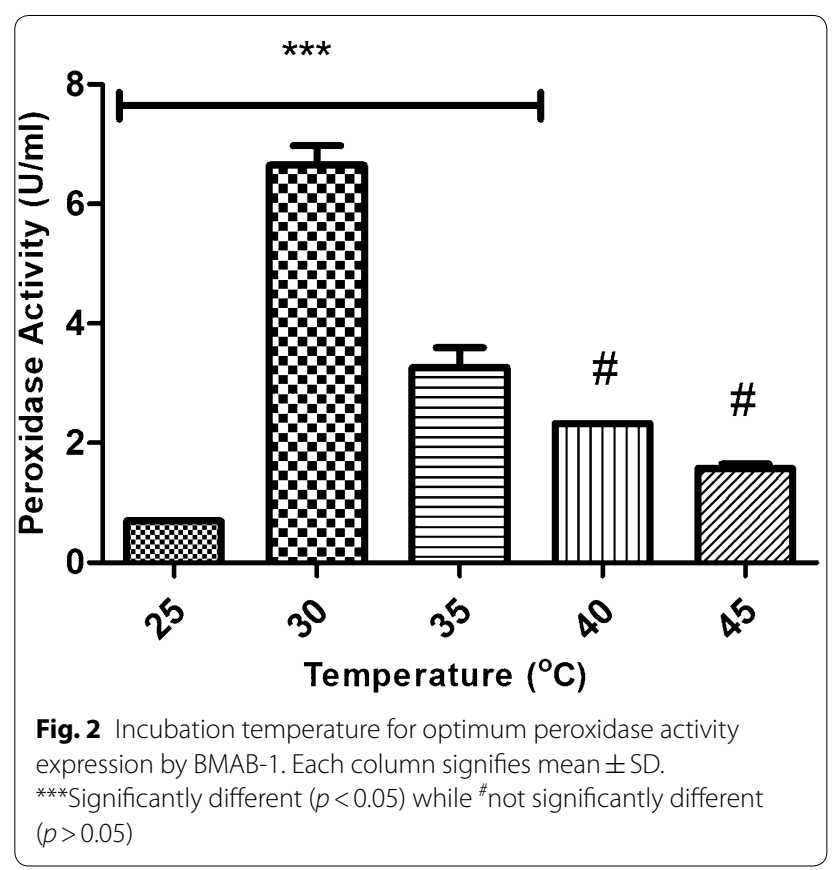


is consistent with some prior related studies, which also reported $150 \mathrm{rpm}$ as the most favourable for bacterial peroxidase secretion (Falade et al. 2019a, 2019d). However, maximum peroxidase yield by Bacillus species was supported at $180 \mathrm{rpm}$ in a different study (Patil 2014). Thus, the effect of agitation on enzyme production varies from individual bacteria.

\section{Influence of lignols on peroxidase activity expression}

Lignols are known inducers of ligninolytic enzymes including peroxidases in bacteria and fungi. Consequently, supplementation of the fermentation medium with the precise lignol may improve peroxidase yield in bacteria with intrinsic peroxidase-producing ability. Therefore, we augmented the carbon source (kraft lignin) in the production medium (KLLM) with selected lignols (Guaiacol-Gua, Veratryl alcohol-VAlc and Vanillin-Van). The influence of lignols on peroxidase activity expression by BMAB-1 is given in Fig. 4. The result showed that peroxidase activity expressed by BMAB-1 grown on lignolsupplemented medium increased significantly $(p<0.05)$ when compared with the non-supplemented production medium, having kraft lignin alone (KLA) as the carbon source (control). While veratryl alcohol induced the highest peroxidase expression in BMAB- $1(2.57 \pm 0.04 \mathrm{U} / \mathrm{ml})$, the control medium induced the lowest peroxidase activity $(0.47 \pm 0.01 \mathrm{U} / \mathrm{ml})$. In other words, veratryl alcohol increased peroxidase activity by over fivefold when compared with the control. This finding agrees with that of Musengi et al (2014), in which veratryl alcohol was also reported as the best peroxidase-inducer in a Streptomyces species. In contrast, guaiacol gave the best inducing

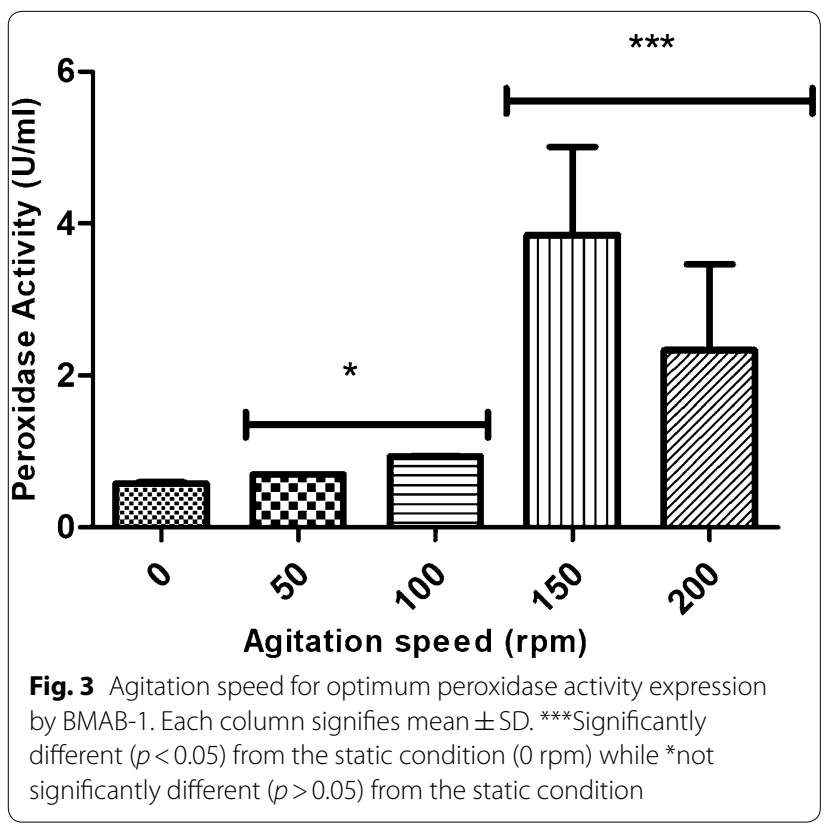

effect on peroxidase expression by Bacillus sp. in a study by Falade et al. (2019d).

\section{Influence of inorganic nitrogen supplementation on peroxidase activity expression}

The impact of nitrogen nature and concentration on the production of different lignocellulolytic enzymes (LCEs) including peroxidases are not constant as this can either be stimulatory or inhibitory (Pedri et al. 2015). Cultivation of bacteria in a medium with precise nitrogen source has been reported to improve enzyme production (Kaal et al. 1995). However, some microbes prefer fermentation medium with limited nitrogen for optimum enzyme production (Galhaup et al. 2002; Gao et al. 2005). This therefore, necessitated augmentation of the production medium with some inorganic sources of nitrogen $\left(\mathrm{NH}_{4} \mathrm{NO}_{3} ; \mathrm{NH}_{4} \mathrm{Cl}\right.$ and $\left.\left(\mathrm{NH}_{4}\right)_{2} \mathrm{SO}_{4}\right)$. The effect of nitrogen supplementation on peroxidase activity expression by BMAB-1 is given in Fig. 5 . The result showed a significant difference $(p<0.05)$ in peroxidase activity expressed by $\mathrm{BMAB}-1$ grown on inorganic nitrogenaugmented medium $\left(\mathrm{YE}+\mathrm{NH}_{4} \mathrm{NO}_{3} ; \mathrm{YE}+\mathrm{NH}_{4} \mathrm{Cl}\right.$ and $\left.\mathrm{YE}+\left(\mathrm{NH}_{4}\right)_{2} \mathrm{SO}_{4}\right)$ when compared with the non-supplemented medium (control): which had yeast extract alone (YEA) as the nitrogen source. While supplementation with $\mathrm{NH}_{4} \mathrm{Cl}$ and $\left(\mathrm{NH}_{4}\right)_{2} \mathrm{SO}_{4}$ produced stimulatory effects on peroxidase activity expression by BMAB-1, with $\left(\mathrm{NH}_{4}\right)_{2} \mathrm{SO}_{4}$ as the best inorganic nitrogen source

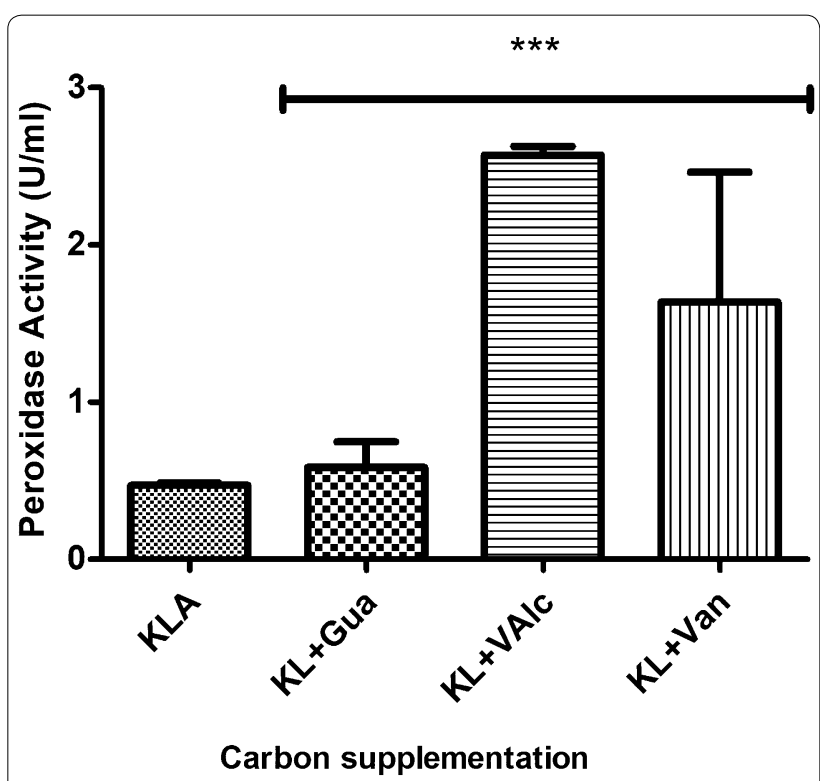

Fig. 4 Influence of lignols on peroxidase activity expression by BMAB-1. Each column signifies mean \pm SD. ***Significantly different $(p<0.05)$ from the control (KLA kraft lignin alone). KL kraft lignin; Gua guaiacol; VAlc veratryl alcohol; Van vanillin 
$(13.07 \pm 0.00 \mathrm{U} / \mathrm{ml})$, addition of $\mathrm{NH}_{4} \mathrm{NO}_{3}$ to the medium repressed peroxidase secretion by $\mathrm{BMAB}-1$. This finding agrees with what we previously reported (Falade et al. 2019d), where augmentation of production medium with $\left(\mathrm{NH}_{4}\right)_{2} \mathrm{SO}_{4}$ supported optimal peroxidase secretion by a Bacillus strain. Meanwhile, addition of both $\mathrm{NH}_{4} \mathrm{NO}_{3}$ and $\mathrm{NH}_{4} \mathrm{Cl}$ was reported to have repressed peroxidase activity expression in the aforementioned study. However, supplementation of organic nitrogen source with $\mathrm{NH}_{4} \mathrm{Cl}$ yielded maximum exoperoxidase activity expression by a Raoultella species (Falade et al. 2019a). These findings further validate the inconsistency in the influence of nitrogen sources on lignocellulolytic enzymes secretion as claimed by Niladevi and Prema (2008).

\section{Time course of peroxidase activity expression}

Expression of peroxidase and non-peroxide dependent enzyme activity by the Bacillus species as well as its cell growth were monitored for $144 \mathrm{~h}$ and the results are given in Fig. 6. The results revealed that BMAB-1 expressed the highest specific peroxidase activity at $72 \mathrm{~h}$ $(17.50 \pm 0.10 \mathrm{U} / \mathrm{mg})$, representing the beginning of stationary growth phase of the bacteria, where production of secondary metabolites mostly occur. It is worthy of note that a non-peroxidase activity was simultaneously expressed by the bacteria, which was however, optimum

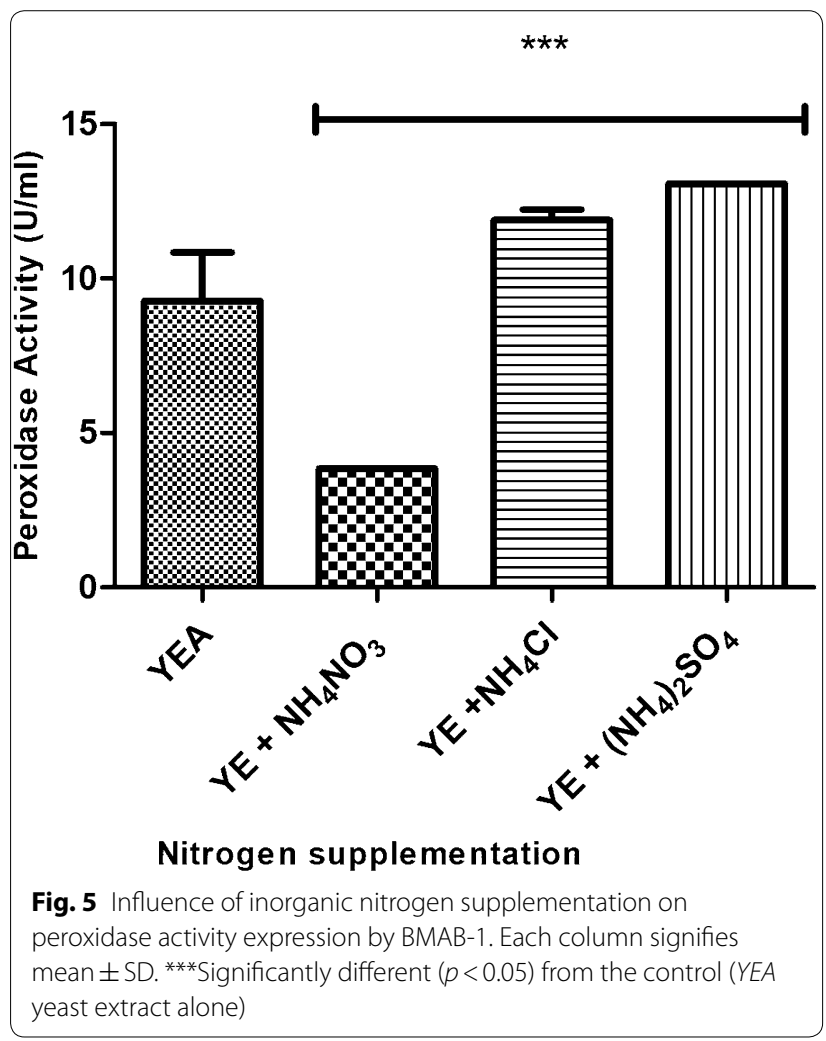

at $48 \mathrm{~h}(10.43 \pm 0.67 \mathrm{U} / \mathrm{mg})$. It is obvious that the enzyme secretion was connected to the bacterial growth. The decline in peroxidase activity expressed after $72 \mathrm{~h}$ is perhaps, due to nutrient exhaustion, "denaturation" or "proteolysis" (Papagianni and Moo-Young 2002). This finding is comparable to some past studies, which also reported optimal peroxidase activity expression at $72 \mathrm{~h}$ (Nour ElDein et al. 2014; Falade et al. 2019a). Nonetheless, other studies have observed optimum peroxidase activity at $48 \mathrm{~h}$ (Falade et al. 2019c, 2019d). It is remarkable that the maximum peroxidase activity expressed by BMAB- 1 is higher than the enzyme yield from other bacteria (Ehiosun and Usman 2018). The optimum peroxidase yield by Raoultella ornithinolytica was $16.48 \pm 0.89 \mathrm{U} / \mathrm{mg}$ at $72 \mathrm{~h}$ (Falade et al. 2019a) while Falade et al. (2019c) reported $12.76 \pm 1.09 \mathrm{U} / \mathrm{mg}$ as the specific peroxidase activity expressed by E. adhaerens NWODO-2 at $48 \mathrm{~h}$. More so, Streptomyces sp K37 achieved $0.537 \mathrm{U} / \mathrm{mg}$ as its optimal specific peroxidase activity (Nour El-Dein et al. 2014), whereas Bacillus sp. FALADE-1 attained optimum peroxidase activity at $48 \mathrm{~h}$ with $8.32 \mathrm{U} / \mathrm{mg}$. Expression of a non-peroxide-dependent extracellular enzyme activity by BMAB-1 probably, suggests laccase activity, as laccase utilizes molecular oxygen as electron acceptor instead of hydrogen peroxide required by peroxidases.

\section{Exploitation of agroresidues for improved peroxidase activity expression}

The imperativeness of the search for new and cheap alternative carbon sources for peroxidase production cannot be overemphasized as the cost of conventional sources of carbon contributes in no small measure to the huge cost of enzyme production, which is still a main obstacle in industrial enzyme production. In a bid to finding a low-cost alternative substrate for sustainable peroxidase

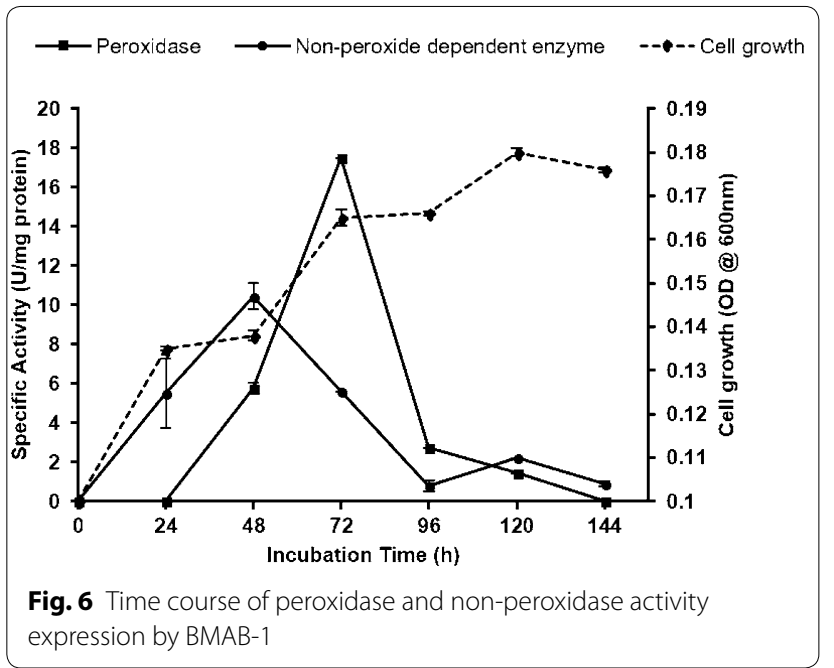


production, we evaluated some agroresidues including sawdust, wheat straw and maize stover as substrates for peroxidase production by BMAB-1. The result, as given in Fig. 7 , showed a significant increase $(p<0.05)$ in peroxidase activity expressed by the bacteria cultivated on the agroresidues when compared with glucose (a standard carbon source) and kraft lignin (a synthetic peroxidase inducer), with sawdust inducing the highest peroxidase activity expression $(47.14 \pm 0.41 \mathrm{U} / \mathrm{mg})$ while the lowest peroxidase activity was induced by glucose $(14.91 \pm 0.31 \mathrm{U} / \mathrm{mg})$. This finding indicates that sawdust would be a suitable alternative to both glucose and kraft lignin as regards peroxidase production. Apart from being cheaper than glucose and other conventional carbon sources, sawdust is more readily available. Hence, utilization of sawdust as substrate by BMAB- 1 would reduce the cost of peroxidase production by the bacteria. Several other studies have also reported sawdust as an effective substrate for production of peroxidase and other ligninolytic enzymes by bacteria (Kamsani et al. 2016; Falade et al. 2019a, 2019c). Falade et al. (2019a) reported $15.21 \pm 2.48 \mathrm{U} / \mathrm{mg}$ as the peroxidase yield by $R$. ornithinolytica $\mathrm{OKOH}-1$ upon utilization of sawdust, which was only comparable to peroxidase activity expressed by the bacteria when grown in a kraft lignin medium $(16.48 \pm 0.89 \mathrm{U} / \mathrm{mg})$. In contrary, sawdust increased peroxidase activity expression in this current study by 2.7 fold when compared with kraft lignin. It is noteworthy that peroxidase yield by BMAB-1 grown on sawdust is significantly higher than what was previously reported. While Falade et al. (2019c) reported $37.50 \mathrm{U} / \mathrm{mg}$ as the specific peroxidase activity expressed by $E$. adhaerens NWODO-2 when grown on sawdust under solid state fermentation, BMAB-1 expressed specific peroxidase activity of $47.14 \pm 0.41 \mathrm{U} / \mathrm{mg}$ when cultivated on sawdust in a submerged fermentation. However, Ijoma et al. (2018) identified wheat straw as the best inducer of manganese peroxidase. The discrepancy in the enzyme titre produced by the test bacteria when cultivated on the different agroresidues as observed in this study may be due to the type and concentration of phenolic and non-phenolic constituents of the substrates.

\section{Conclusion}

BMAB-1 exhibited the characteristic of an acidophile as it expressed optimum exoperoxidase activity at $\mathrm{pH} 5$ and considerable activity was expressed by the bacteria at extreme $\mathrm{pH} 3$ and 4 . Maximum peroxidase yield by the bacteria was supported at $30{ }^{\circ} \mathrm{C}$ and $150 \mathrm{rpm}$ while augmentation of the production medium with veratryl alcohol and ammonium sulphate improved peroxidase activity expression by BMAB-1 significantly. This study showed that agricultural residues are excellent

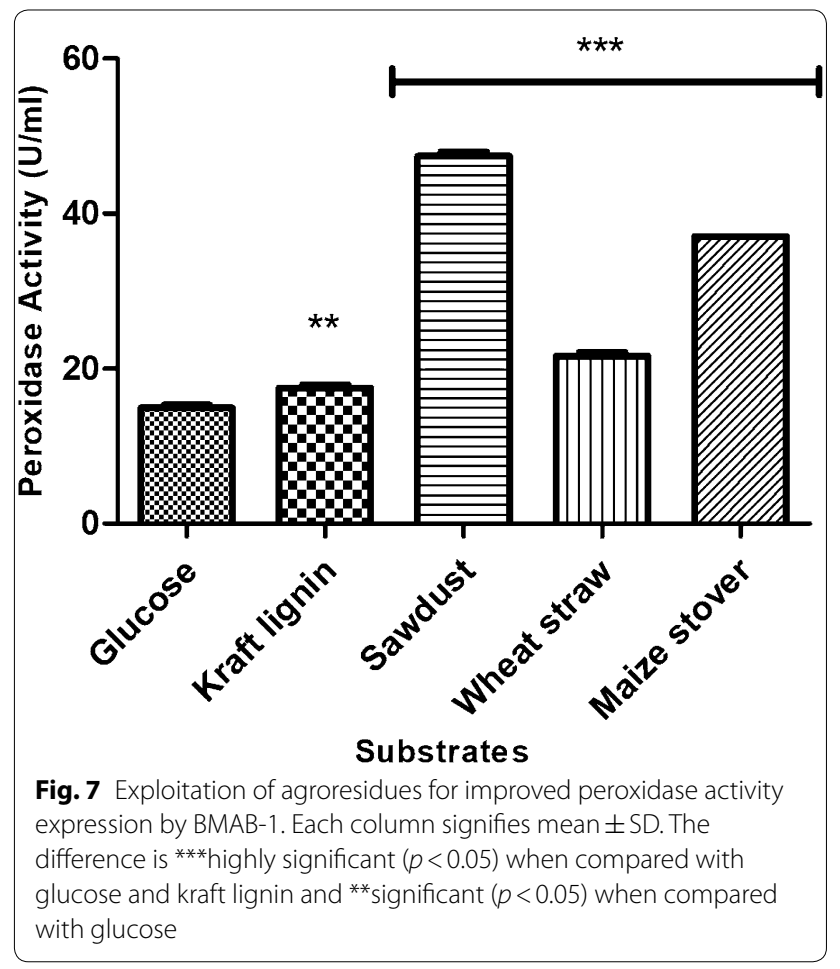

bioresources for enhanced peroxidase production because all the investigated agroresidues (sawdust, wheat straw and maize stover) improved peroxidase activity expression by BMAB-1. However, the bacteria showed the most remarkable peroxidase activity on sawdust because the substrate improved peroxidase yield by 3.2-fold and 2.7-fold when compared with glucose and kraft lignin, respectively. Thus, sawdust would be a suitable alternative to the conventional carbon sources and kraft lignin for peroxidase production by the bacteria. Furthermore, the ability of BMAB-1 to utilize agroresidues would reduce the cost of peroxidase production since agricultural residues are cheaper than the conventional carbon sources and as well are more readily available.

\section{Abbreviations \\ ANOVA: Analysis of variance; BLAST: Basic local alignment search tool; BMAB- 1: Bacillus sp. MABINYA-1; KLA: Kraft lignin alone; KLLM: Kraft lignin liquid medium; LCEs: Lignocellulolytic enzymes; NCBI: National Center for Biotech- nology Information; OD: Optical density; OVAT: One-variable-at-a-time; SMF: Submerged fermentation; YEA: Yeast extract alone.}

\section{Acknowledgements} Not applicable.

\section{Authors' contributions}

Conceptualization: AO, LV, Al and UU. Investigation: AO. Data curation and analysis: AO. Writing —original draft preparation: AO. Writing — review and editing: LV, Al and UU. Supervision: LV, Al and UU. All authors read and approved the final manuscript. 


\section{Funding}

This work received financial support from the National Research Foundation (NRF), South Africa [grant number: 95364] and South African Medical Research Council [Grant number: UFH/P790].

\section{Availability of data and materials}

All data generated or analyzed during this study are included in this article.

\section{Ethics approval and consent to participate}

Not applicable.

\section{Consent for publication}

Not applicable.

\section{Competing interests}

Authors declare that they have no competing interests.

\section{Author details}

1 SAMRC Microbial Water Quality Monitoring Centre, University of Fort Hare, Private Bag X1314, Alice 5700, Eastern Cape, South Africa. ${ }^{2}$ Applied and Environmental Microbiology Research Group (AEMREG), Department of Biochemistry and Microbiology, University of Fort Hare, Private Bag X1314, Alice 5700, Eastern Cape, South Africa. ${ }^{3}$ Department of Biochemistry, University of Medical Sciences, Ondo 351101, Ondo State, Nigeria.

Received: 30 July 2020 Accepted: 14 October 2020

Published online: 22 October 2020

\section{References}

Arnau J, Yaver D, Hjort CM (2020) Strategies and challenges for the development of industrial enzymes using fungal cell factories. In: Nevalainen $H$ (ed) Grand Challenges in Fungal Biotechnology, Grand Challenges in Biology and Biotechnology. Springer Nature, Switzerland, pp 179-210

Bradford MM (1976) A rapid and sensitive method for the quantitation of microgram quantities of protein utilizing the principle of protein-dye binding. Anal Biochem 72:248-254

Chance B, Maehly AC (1955) Assay of catalases and peroxidases. Methods Enzymol 2:773-775

Dumorne K (2018) Biotechnological and industrial applications of enzymes produced by extremophilic bacteria. A mini review. Preprints. https://doi. org/10.20944/preprints201801.0198.v1

Ehiosun Kl, Usman M (2018) Evaluation of crude oil biodegradation efficiency and peroxidase production by Streptomyces albus. J Appl Sci Environ Manage 22(2):213-217

Falade A, Mabinya L, Okoh A, Nwodo U (2019a) Peroxidases produced by new ligninolytic Bacillus strains isolated from marsh and grassland decolourized anthraquinone and azo dyes. Pol J Environ Stud 28(5):3163-3172

Falade AO, Jaouani A, Mabinya LV, Okoh Al, Nwodo UU (2019) Exoproduction and molecular characterization of peroxidase from Ensifer adhaerens. Appl Sci 9:3121

Falade AO, Eyisi OAL, Mabinya LV, Nwodo UU, Okoh Al (2017) Peroxidase production and ligninolytic potentials of freshwater bacteria Raoultella ornithinolytica and Ensifer adhaerens. Biotechnol Rep 16:12-17

Falade AO, Mabinya LV, Okoh Al, Nwodo UU (2018) Ligninolytic enzymes: versatile biocatalysts for the elimination of endocrine-disrupting chemicals in wastewater. MicrobiologyOpen 7:e722

Falade AO, Mabinya LV, Okoh Al, Nwodo UU (2019b) Agrowastes utilization by Raoultella ornithinolytica for optimal extracellular peroxidase activity. Biotechnol Appl Biochem 66:60-67

Falade AO, Mabinya LV, Okoh Al, Nwodo UU (2019c) Studies on peroxidase production and detection of Sporotrichum thermophile-like catalase-peroxidase gene in a Bacillus species isolated from Hogsback forest reserve. South Africa Heliyon 5:e03012

Falade AO, Nwodo UU, Iweriebor BC, Green E, Mabinya LV, Okoh AI (2017) Lignin peroxidase functionalities and prospective applications. MicrobiologyOpen 6:e00394

Galhaup C, Wagner H, Hinterstoisser B, Haltrich D (2002) Increased production of laccase by the wood-degrading basidiomycete Trametes pubescens. Enzyme Microb Technol 30:529-536
Gao D, Wen X, Qian Y (2005) Effect of nitrogen concentration in culture medium on growth and enzyme production of Phanerochaete chrysosporum. J Environ Sci 17(2):190-193

Ijoma GN, Selvarajan R, Tekere M (2018) The potential of fungal co-cultures as biological inducers for increased ligninolytic enzymes on agricultural residues. Int J Environ Sci Technol. https://doi.org/10.1007/s1376 2-018-1672-4

Jackson BR, Noble C, Lavesa-Curto M, Bond PL, Bowater RP (2007) Characterization of an ATP-dependent DNA ligase from the acidophilic archaeon "Ferroplasma acidarmanus" Fer1. Extremophiles 11:315-327

Kaal EEJ, Field JA, Joyce TW (1995) Increasing ligninolytic enzyme activities in several white-rot basidiomycetes by nitrogen sufficient media. Bioresour Technol 53:133-139

Kamsani N, Salleh MM, Yahya A, Chong CS (2016) Production of lignocellulolytic enzymes by microorganisms isolated from Bulbitermes sp. termite gut in solid-state fermentation. Waste Biomass Valor 7:357

Kumar A, Singh AK, Ahmad S, Chandra R (2020) Optimization of laccase production by Bacillus sp strain AKRC01 in presence of agro-waste as effective substrate using response surface methodology. J Pure Appl Microbiol 14(1):1-12

McNeil B, Harvey LM, Giavasis I (2006) The effect of agitation and aeration on the synthesis and molecular weight of gellan in batch cultures of Sphingomonas paucimobilis. Enzyme Microb Technol 38:101-108

Min K, Gong G, Woo HM, Kim Y, Um Y (2015) A dye-decolorizing peroxidase from Bacillus subtilis exhibiting substrate-dependent optimum temperature for dyes and -ether lignin dimer. Sci Rep 5:8245

Musengi A, Khan N, Le Roes-Hill M, Pletschke BI (2014) Increasing the scale of peroxidase production by Streptomyces sp. strain BSII\# 1. J Appl Microbiol 116:554-562

Niladevi KN, Prema P (2008) Effect of inducers and process parameters on laccase production by Streptomyces psammoticus and its application in dye decolourization. Bioresour Technol 99:4583-4589

Nour El-Dein MM, Shereif AEA, Mansour FA, Abou-Dobara MI, Ball AS (2014) Optimization of xylanase and peroxidase production from Streptomyces sp. K37. J BioSci Biotech 3:29-42

Papagianni M, Moo-Young M (2002) Protease secretion in glucoamylase producer Aspergillus niger cultures: Fungal morphology and inoculum effects. Process Biochem 37:1271-1278

Patil SR (2014) Production and purification of lignin peroxidase from Bacillus megaterium and its application in bioremediation. CIBTech J Microbiol 3:22-28

Pedri ZC, Lozano LMS, Hermann KL, Helm CV, Peralta RM, Tavares LBB (2015) Influence of nitrogen sources on the enzymatic activity and grown by Lentinula edodes in biomass Eucalyptus benthamii. Braz J Biol. https://doi. org/10.1590/1519-6984.03214

Rajkumar R, Yaakob Z, Takriff MS, Kamarudin KF (2013) Optimization of medium composition for production of peroxidase by Bacillus sp. Der Pharma Chemica 5:167-174

Rao PR, Kavya P (2014) Production, isolation and purification of peroxidase using Bacillus subtilis. $20141^{\text {st }}$ International Congress on Environmental, Biotechnology, and Chemistry Engineering. IPCBEE 64:21-27

Ray AK, Bairagi A, Ghosh KS, Sen SK (2007) Optimization of fermentation conditions for cellulase production by Bacillus subtilis CY5 and Bacillus circulans TP3 isolated from fish gut Acta Ichthyol. Piscat 3:47-53

Regalado C, Garcia-Almendarez BE, Duarte-Vazquez MA (2004) Biotechnological applications of peroxidases. Phytochem Rev 3:243-256

Saleem R, Khurshid M, Ahmed S (2018) Laccases, manganese peroxidases and xylanases used for the bio-bleaching of paper pulp: an environmental friendly approach. Protein peptide lett 25:180-186

Sharma A, Parashar D, Satyanarayana T (2016) Acidophilic microbes: biology and applications. In: Rampelotto PH (ed) Biotechnology of extremophiles, grand challenges in biology and biotechnology, vol 1. Springer International Publishing, Switzerland, pp 215-241

Taboada-Puig R, Lu-Chau TA, Eibes G, Feijoo G, Moreira MT, Lema JM (2015) Continuous removal of endocrine disruptors by versatile peroxidase using a two-stage system. Biotechnol Proc 31:908-916

Tandon D, Sharma N (2014) Isolation of potential novel cellulolytic and xylanolytic bacteria and optimization of their cultural conditions for enhanced production of cellulase and xylanase. J Agroaliment Proc Technol 20:231-240 
Taylor CR, Hardiman EM, Ahmad M, Sainsbury PD, Norris PR, Bugg TDH (2012) Isolation of bacterial strains able to metabolize lignin from screening of environmental samples. J Appl Microbiol 113(3):521-530

Tuncer M, Rob A, Ball AS, Wilson MT (1999) Optimisation of extracellular lignocellulolytic enzyme production by a thermophilic actinomycete Thermomonospora fusca BD25. Enzym Microb Technol 25:38-47

Unuofin JO, Okoh Al, Nwodo UU (2019) Maize stover as a feedstock for enhanced laccase production by two gamma proteobacteria: a solution to agroindustrial waste stockpiling. Ind Crop Prod 129:611-623
Wang FQ, Xie H, Chen W, Wang ET, Du FG, Song AD (2013) Biological pretreatment of corn stover with ligninolytic enzyme for high efficient enzymatic hydrolysis. Bioresour Technol 144:572-578

\section{Publisher's Note}

Springer Nature remains neutral with regard to jurisdictional claims in published maps and institutional affiliations.

\section{Submit your manuscript to a SpringerOpen ${ }^{\circ}$ journal and benefit from:}

- Convenient online submission

- Rigorous peer review

- Open access: articles freely available online

- High visibility within the field

Retaining the copyright to your article

Submit your next manuscript at $\boldsymbol{\nabla}$ springeropen.com 